\title{
EFFECT OF THE PLACEMENT OF FERTILIZER ON THE DEVELOPMENT OF SPRING WHEAT
}

\author{
ERKKI AURA \\ University of Helsinki, Department of Agricultural Chemistry
}

Received May 31, 1967

In Finland fertilizers are usually broadcast. They are only covered with soil by harrowing, and it is supposed that the nutrients would move downwards to the layers where the plant roots are able to take up their ions.

However, recent observations indicate that the old suppositions are not always valid. KaIla and Hänninen (1961) found that even the easily movable nitrate nitrogen applied as a surface dressing tended to remain in the surface layer of 0 to $5 \mathrm{~cm}$ for the early part of the summer, which usually is quite dry in Finland.

In order to study the effect of placement on the uptake of nutrients shoot and soil samples were collected in 1965 from a field experiment on spring wheat described by ELONEN et al. (1967). The effect of placement was compared with that of surface dressing.

\section{Experimental}

The experimental soil was silty clay. The average particle size distribution was: $<0.002 \mathrm{~mm} 47 \%, 0.002-0.02 \mathrm{~mm} 36 \%, 0.02-0.2 \mathrm{~mm} 13 \%$ and $0.2-2 \mathrm{~mm} 4 \%$. Soil $\mathrm{pH}$ was measured in 1:2.5 suspension in $0.01 \mathrm{M} \mathrm{CaCl}_{2}$ and it was, on the average, 5.9. Organic carbon was estimated by the procedure of Walkley-Black. The average content was $5.4 \%$. CEC was calculated as the sum of exchangeable bases and hydrogen. The exchangeable bases were determined by the method of TERÄsvUORI (1959) and the exchangeable hydrogen by the method of Schofield (1933). The average CEC was $32 \mathrm{me} / 100 \mathrm{~g}$ and $\mathrm{BS} 78 \%$.

The broadcasted fertilizer was covered with soil only by the coulters of the sowing machine. Fertilizer was placed in the depths of 8 and $12 \mathrm{~cm}$. Two amounts of a Finnish compound fertilizer $(\mathrm{N}-\mathrm{P}-\mathrm{K}=8-5.7-7.5)$ were used: 550 and $1000 \mathrm{~kg} / \mathrm{ha}$. Three fourths of the fertilizer nitrogen is in the form of ammonium and one fourth in the form of nitrate. All of the phosphorus is added in fertilizer as superphosphate and about a half of the phosphorus of compound fertilizer is watersoluble. Potassium is added in fertilizer as potassium chloride. The seed of spring wheat was sown about to the depth of $5 \mathrm{~cm}$. 
There was a special sampling area in each plot. The shoot samples were collected from an area of $0.88 \mathrm{~m}^{2}$ on each plot. The soil samples were taken with a special core sampler (HEINONEN 1960). The distance of fertilizer rows was $15 \mathrm{~cm}$ and the diameter of the sampler cylinder was $5.3 \mathrm{~cm}$. At each sampling 5-10 cores were taken per plot and samples from the same layer of the plot were brought together and mixed.

Total nitrogen of plant material was analysed by the Kjeldahl method. Total phosphorus was determined with the ammonium vanadate method and total potassium flamephotometrically from ash dissolved in $\mathrm{HC1}$. Ammonium and nitrate nitrogen of soil were extracted from fresh samples with $0.5 \mathrm{~N} \mathrm{~K}_{2} \mathrm{SO}_{4}$ in the ratio 1:5. Ammonium nitrogen was determined by steam distillation. Ammonia was released from the extract by solution, which contained $0.5 \mathrm{~N} \mathrm{NaOH}$ and $4 \% \mathrm{H}_{3} \mathrm{BO}_{3}$ in the ratio of 1:4. Fractions of inorganic phosphorus in the airdried samples were studied by the procedure of CHANG and JAckson (1957). Exchangeable potassium was extracted by $1 \mathrm{~N}$ ammonium acetate.

\section{The development of wheat}

The first shoot samples were taken on the 18th of June 37 days after the sowing. At that time wheat was about $15 \mathrm{~cm}$ high. The second time shoot samples were collected on the 8 th of July about 4 days before ear emergence.

Table 1. Dry weights and nutrient contents of shoots as $\mathrm{kg} / \mathrm{ha}$ on June 18 th and on July 8 th.

\begin{tabular}{|c|c|c|c|c|c|c|c|}
\hline \multirow[b]{2}{*}{$\begin{array}{l}\text { Fertilizer } \\
\text { kg/ha }\end{array}$} & \multicolumn{3}{|c|}{ June 18} & & \multicolumn{3}{|c|}{ July 8} \\
\hline & $\begin{array}{l}\text { Surface } \\
\text { dressing }\end{array}$ & Placement & Average & & $\begin{array}{l}\text { Surface } \\
\text { dressing }\end{array}$ & Placement & Average \\
\hline & & & & Dry weights & & & \\
\hline 550 & 151 & 223 & 187 & & 935 & 1593 & 1264 \\
\hline 1000 & 132 & 223 & 178 & & 802 & 1839 & 1320 \\
\hline \multirow{3}{*}{ Average } & 142 & 223 & & & 868 & 1716 & \\
\hline & \multicolumn{3}{|c|}{ Effect of placement $+81^{* *}$} & & \multicolumn{3}{|c|}{ Effect of placement $+848 * * *$} \\
\hline & & & & Nitrogen & & & \\
\hline 550 & 4.4 & 9.7 & 7.0 & & 27 & 52 & 40 \\
\hline 1000 & 3.9 & 10.8 & 7.3 & & 23 & 55 & 39 \\
\hline \multirow[t]{3}{*}{ Average } & 4.2 & 10.2 & & & 25 & 54 & \\
\hline & \multirow{2}{*}{\multicolumn{3}{|c|}{ Effect of placement $+6.1^{* * *}$}} & & \multicolumn{3}{|c|}{ Effect of placement $+29 * * *$} \\
\hline & & & & Phosphorus & & & \\
\hline 550 & 0.55 & 0.84 & 0.70 & & 3.4 & 5.0 & 4.2 \\
\hline 1000 & 0.46 & 0.92 & 0.69 & & 2.9 & 6.1 & 4.5 \\
\hline \multirow[t]{3}{*}{ Average } & 0.51 & 0.88 & & & 3.2 & 5.6 & \\
\hline & \multirow{2}{*}{\multicolumn{3}{|c|}{$\overline{\text { Effect of placement }+0.37 * * *}$}} & & \multicolumn{3}{|c|}{ Effect of placement $+2.5 * * *$} \\
\hline & & & & Potassium & & & \\
\hline 550 & 4.9 & 9.0 & 7.0 & & 30 & 46 & 38 \\
\hline 1000 & 4.4 & 11.4 & 7.9 & & 26 & 56 & 41 \\
\hline \multirow[t]{2}{*}{ Average } & 4.7 & 10.2 & & & 28 & 51 & \\
\hline & \multicolumn{3}{|c|}{ Effect of placement $+5.5^{* * *}$} & & \multicolumn{3}{|c|}{ Effect of placement $+23 * * *$} \\
\hline
\end{tabular}


According to Table 1 the placement gave much better growth of shoots than the surface dressing. The amount of fertilizer $1000 \mathrm{~kg} / \mathrm{ha}$ did not cause significantly better early growth than the lower amount.

The analyses of shoot samples showed that the placement caused higher uptake of nutrients by wheat plants than the surface dressing. The total nitrogen content of the plants growing on the soil which received placement, was twice as high as that of plants which grew on plots receiving surface dressing. The results of phosphorus and potassium analyses resemble those of nitrogen analyses. However, it seems that the placing increased relatively most the uptake of nitrogen, to a lower degree that of potassium and least that of phosphorus compared with the surface dressing. In the plots receiving placement, increasing the fertilizer amount improved slightly the uptake of nutrients. This was not the case in the plots receiving surface dressing.

The ear emergence was statistically highly significantly speeded up by the placement compared with the surface dressing, on the average, with four days. At the harvest the moisture of grain was on the plots with placed fertilizer about two per cent units lower than on the plots receiving surface dressing. Thus the placement speeded up also the ripening of the wheat.

The grain yields (dry matter $\mathrm{kg} / \mathrm{ha}$ ) (ELONEN et al. 1967) were the following:

$\begin{array}{ccccc}\begin{array}{c}\text { Amount of } \\ \text { fertilizer }\end{array} & \begin{array}{c}\text { Surface } \\ \text { dressing }\end{array} & \begin{array}{c}\text { Placement } \\ 8 \mathrm{~cm}\end{array} & \begin{array}{c}\text { Placement } \\ 12 \mathrm{~cm}\end{array} & \text { Average } \\ \mathrm{kg} / \mathrm{ha} & & & & \\ 550 & 1411 & 1678 & 1673 & 1587 \\ 1000 & 1510 & 2069 & 2023 & 1867 \\ \text { Average } & 1461 & 1874 & 1848 & \end{array}$

The placement of fertilizer in the depth of $8 \mathrm{~cm}$ gave $28 \%$ greater grain yield than the surface dressing. The placement of fertilizer in the depth of $12 \mathrm{~cm}$ caused slightly lower grain yield than that in $8 \mathrm{~cm}$. When the fertilizers were applied as a surface dressing the raising of the amount from $550 \mathrm{~kg} / \mathrm{ha}$ to $1000 \mathrm{~kg} / \mathrm{ha}$ increased grain yield only $7 \%$, but when the fertilizers were placed, the increase in yield was $23 \%$.

\section{Distribution of nutrients in the experimental soil}

The data in Table 2 show that a great deal of fertilizer nitrogen was found on the 19th of June in the layer of $0-5 \mathrm{~cm}$ in the plot 91 which received surface dressing. Even the content of nitrate nitrogen was quite marked near the surface. This was due to the very dry weather during the early part of summer. The precipitation from the sowing to the collection of the samples (May 12 - June 18) was only $28 \mathrm{~mm}$.

The same plot received in the period June 19 - July $569 \mathrm{~mm}$ of water. On July 5 nitrate nitrogen seems to have moved to the depth of $10-15 \mathrm{~cm}$. On the contrary the content of ammonium nitrogen of the different layers did not change to an extent possible to detect by these methods.

The results of the plot 92 show that $37 \mathrm{~mm}$ of water, which was given on June $19-20$ seems to have leached nitrate nitrogen to the depth of $7.5-10 \mathrm{~cm}$. 
Table 2. $\mathrm{NH}_{4}-\mathrm{N}$ and $\mathrm{NO}_{3}-\mathrm{N}$ (ppm) in various depths. The amount of fertilizer $1000 \mathrm{~kg} / \mathrm{ha}$.

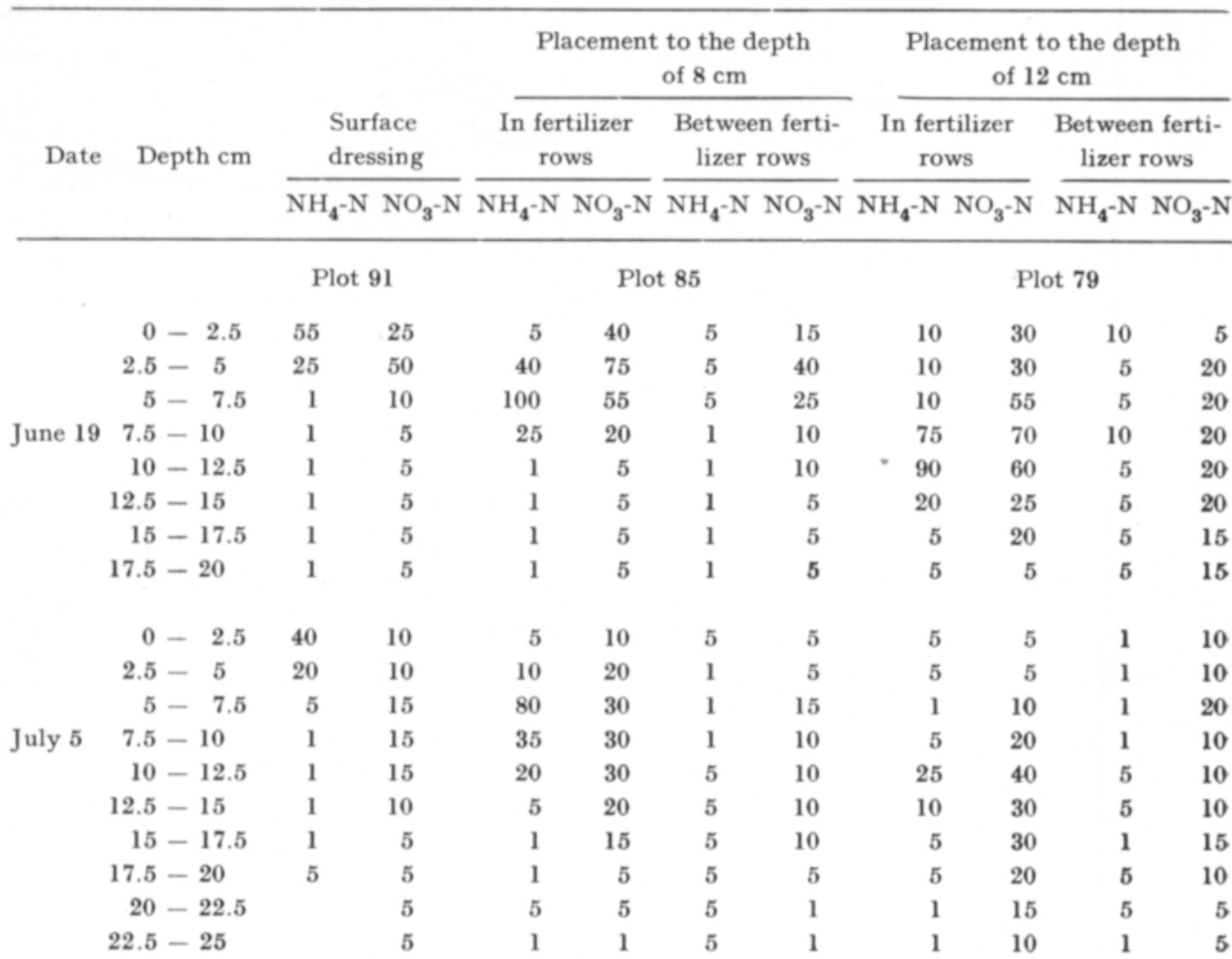

\section{Plot 92}

$\begin{array}{crrr}0-2.5 & 50 & 25 \\ 2.5-5 & 15 & 25 \\ 5-7.5 & 5 & 20 \\ \text { June } 21 & 7.5-10 & 5 & 25 \\ 10-12.5 & 5 & 5 \\ 12.5-15 & 5 & 5 \\ 15-17.5 & 5 & 1 \\ 17.5-20 & 5 & 5 \\ 20-22.5 & 1 & 5 \\ 22.5-25 & 1 & 1 \\ & & \\ 0-2.5 & 30 & 50 \\ 2.5-5 & 10 & 35 \\ 5-7.5 & 5 & 10 \\ 7.5-10 & 1 & 5 \\ 10-12.5 & 5 & 1 \\ 12.5-15 & 5 & 5 \\ 15-17.5 & & 5 \\ 17.5-20 & & 5 \\ 20-22.5 & & 5 \\ 22.5-25 & & 1\end{array}$

\section{Plot 86}

$\begin{array}{rrrr}1 & 15 & 5 & 10 \\ 1 & 30 & 1 & 10 \\ 115 & 60 & 1 & 10 \\ 40 & 85 & 1 & 10 \\ 1 & 30 & 1 & 10 \\ 1 & 10 & 5 & 5 \\ 5 & 5 & 5 & 10 \\ 5 & 5 & 5 & 5 \\ 1 & 5 & 5 & 5 \\ 1 & 1 & 5 & 1\end{array}$

\section{Plot 80}

$\begin{array}{rrrr}5 & 5 & 1 & 5 \\ 1 & 5 & 1 & 5 \\ 1 & 10 & 1 & 5 \\ 5 & 40 & 5 & 10 \\ 90 & 70 & 1 & 15 \\ 30 & 60 & 1 & 10 \\ 5 & 35 & 1 & 10 \\ 5 & 15 & 1 & 5 \\ 1 & 15 & 1 & 5 \\ 1 & 10 & 1 & 10\end{array}$

$\begin{array}{rrrr}5 & 10 & 5 & 10 \\ 1 & 10 & 1 & 10 \\ 5 & 5 & 5 & 5 \\ 5 & 5 & 1 & 5 \\ 15 & 25 & 1 & 5 \\ 15 & 20 & 1 & 10 \\ 10 & 15 & 1 & 10 \\ 5 & 10 & 1 & 5 \\ 5 & 10 & & 10 \\ 1 & 5 & & 10\end{array}$


In the top layer of $0-2.5$ the nitrate nitrogen content increased in the period June 21 - July 6. This fact is due to the nitrification or movement of nitrate upwards.

In the plots receiving placement most of nitrogen was found in a deeper layer and better within the reach of roots than in the plots receiving surface dressing. Probably ammonium nitrogen has remained in the placing depth, which in the plots 85 and 86 was somewhat less than $8 \mathrm{~cm}$. If the distribution of nitrate nitrogen is compared with that of ammonium nitrogen, it is noticed, that probably nitrate nitrogen has moved upwards, downwards and to the sides. In plots 79 and 80 receiving placement in the depth of $12 \mathrm{~cm}$, water leached nitrate nitrogen below the plough layer or below $20 \mathrm{~cm}$. However, it can not be noticed, that even $69 \mathrm{~mm}$ of water, which was received in the period June 19 - July 5, would have leached nitrate effectively.

In general less nitrogen was found on the 5th and 6 th of July than on the 19th and 21 th of June. This fact is obviously due to the uptake of nitrogen by plants.

Table 3. Easily soluble, aluminium and iron bound phosphorus (ppm) in various depths. The amount of fertilizer $1000 \mathrm{~kg} / \mathrm{ha}$.

\begin{tabular}{|c|c|c|c|c|c|c|c|c|c|}
\hline \multirow[b]{3}{*}{$\begin{array}{c}\text { Depth } \\
\mathrm{cm}\end{array}$} & & & & \multicolumn{6}{|c|}{ Placement to the depth of $8 \mathrm{~cm}$} \\
\hline & \multicolumn{3}{|c|}{ Surface dressing } & \multicolumn{3}{|c|}{ In fertilizer rows } & \multicolumn{3}{|c|}{ Between fertilizer rows } \\
\hline & $\begin{array}{l}\text { Easily } \\
\text { soluble }\end{array}$ & Al-P & Fe-P & $\begin{array}{l}\text { Easily } \\
\text { soluble }\end{array}$ & Al-P & $\mathrm{Fe}-\mathrm{P}$ & $\begin{array}{c}\text { Easily } \\
\text { soluble }\end{array}$ & $\mathrm{Al}-\mathrm{P}$ & $\mathrm{Fe}-\mathrm{P}$ \\
\hline $0-2.5$ & 4 & 125 & 235 & 2 & 75 & 215 & 1 & 80 & 210 \\
\hline $2.5-5$ & 3 & 90 & 220 & 3 & 90 & 220 & 1 & 70 & 215 \\
\hline $5-7.5$ & 2 & 80 & 215 & 20 & 240 & 290 & 1 & 75 & 215 \\
\hline $7.5-10$ & 2 & 75 & 190 & 7 & 155 & 265 & 1 & 60 & 200 \\
\hline $10-12.5$ & & & & 1 & 90 & 205 & & & \\
\hline
\end{tabular}

The results of the fractionation of soil phosphorus are reported in Table 3. In soil receiving surface dressing the contents of easily soluble phosphorus, aluminium bound and iron bound phosphorus were highest in the layer of $0-5 \mathrm{~cm}$. In soil receiving placement the corresponding fractions were highest in the depth, in which the fertilizer was placed.

Table 4. Exchangeable potassium in various depths $\frac{\mathrm{me}}{100 \mathrm{~g}}$. The amount of fertilizer $1000 \mathrm{~kg} / \mathrm{ha}$.

\begin{tabular}{|c|c|c|c|c|c|}
\hline \multirow[b]{2}{*}{ Depth } & \multirow[b]{2}{*}{ Sampling } & \multicolumn{2}{|c|}{ Surface dressing } & \multicolumn{2}{|c|}{$\begin{array}{l}\text { Placement to the depth of } 8 \mathrm{~cm} \\
\text { In fertilizer rows }\end{array}$} \\
\hline & & June 19 & July 5 & June 19 & July 5 \\
\hline $0-2.5$ & & 0.92 & 0.94 & 0.55 & 0.64 \\
\hline $2.5-5$ & & 0.75 & 0.80 & 0.63 & 0.64 \\
\hline $5-7.5$ & & 0.63 & 0.56 & 1.26 & 0.94 \\
\hline $7.5-10$ & & 0.63 & 0.56 & 0.86 & 0.96 \\
\hline $10-12.5$ & & & & 0.61 & 0.70 \\
\hline
\end{tabular}


The content of exchangeable potassium was also in plots receiving surface dressing highest in the layer of $0-5 \mathrm{~cm}$ (Table 4). In soil receiving placement the highest content of exchangeable potassium was found in the depth of the placing.

\section{Discussion}

The placement of fertilizer caused much better growth and uptake of nutrients than the surface dressing. This result can be explained by the distribution of nutrients in soil during the dry early part of the summer. A great deal of nutrients, which were applied as a surface dressing, remained in the surface layer of $0-5 \mathrm{~cm}$. According to the results, not only the content of ammonium nitrogen, but also that of nitrate nitrogen was highest in the depth of $0-5 \mathrm{~cm}$.

When fertilizer was placed, the highest content of nutrients was in the placing depth. Thus nutrients were located in moister soil and better within the reach of roots than applied as a surface dressing.

The better growth caused by the placement is obviously due to the fact that during dry period surface layers become dry more quickly than deeper layers. Thus in soil, where a great deal of nutrients was located near surface, the uptake of nutrients by plants was difficult. The drying of soil probably has prevented ions from diffusion into roots, or the roots which were located in the surface layer had weakened physiologically. It is also possible that there were no roots near the surface.

The results confirm the investigations of KAILA and HännINEN (1961), who showed that nitrogen applied as a surface dressing is to a great extent ineffective during dry periods.

When nutrients were primarily located in the depth of $5-10 \mathrm{~cm}$, the grain yield of wheat was slightly higher than when nutrients were mainly located in the depth of $10-15 \mathrm{~cm}$, although because of the dry early part of the summer, the nutrients placed deep have probably been in moister soil than nutrients placed low. It is possible that when the fertilizer was placed in the depth of $12 \mathrm{~cm}$, the coulters of fertilizer drill have tilled soil too effectively, which has dried the soil and reduced sprouting. It was noticed, that the sprouting was slightly lower on the plots receiving the placement in the depth of $8 \mathrm{~cm}$ and more lower on those receiving the placement in the depth of $12 \mathrm{~cm}$ than in the plots receiving surface dressing. However, the differences were not significant. It is also possible that when the fertilizer was placed in $12 \mathrm{~cm}$ plants suffered from the lack of nutrients in the early stage of growth because of too short roots.

According to the results the uptake of nitrogen was relatively more improved by the placement than the uptake of phosphorus and potassium. This fact is obviously due to the available resources of phosphorus and potassium, which have not been given as a dressing. The speeding up of ripening by placement compared with the surface dressing is probably caused by the increased early uptake of nitrogen and the increased uptake of phosphorus by means of the placement.

Any movement of ammonium nitrogen was not detected by these methods, and probably also the movement of phosphorus and potassium was slight. Nitrate nitrogen appeared to move to a greater extent particularly in the irrigated plots. The 
results are in accord with foreign investigations (TYLER et al. 1958, GoldEN 1961, Munson \& Nelson 1963). According to the results, it is not likely that even great amounts of water would leach nitrate nitrogen in clay soil from the reach of plant roots during the growth season. This probably is not the case in sand and fine sand soils.

Attention must be payed to the fact that the placement is advantageous, when great amounts of fertilizer are used. It could already be noticed by means of the shoot samples that on the plots receiving placement the increase of fertilizer amount improved the growth of shoots and the uptake of nutrients by shoots to a greater extent than on the plots receiving surface dressing. However, only the grain yields showed that the interaction of the application method and the amount of fertilizer is significant.

The fact that the broadcast fertilizer was covered with soil only by the coulters of sowing machine, and the rather dry early summer have probably caused an unusual great difference between the effects of the placement and the broadcast.

\section{$S u m m$ ary}

The placement of fertilizer was studied in the field trial on a clay soil in Southern Finland. The placement of fertilizer in the depth of $8 \mathrm{~cm}$ gave 28 per cent greater grain yield of spring wheat, and the placement in the depth of $12 \mathrm{~cm} 26$ per cent greater grain yield than the surface dressing.

The growth of shoots on the soil receiving placement was much better than on the soil receiving surface dressing. The results of shoot analyses showed that the placement caused a much greater uptake of nutrients than the surface dressing. The uptake of nitrogen was relatively most increased by the placement, somewhat less that of potassium and least that of phosphorus.

The ripening of wheat was speeded up by the placement, which probably was due to the better early uptake of nitrogen and to the better uptake of phosphorus by means of the placing.

The superiority of the placement to the surface dressing could be explained by the distribution of nutrients in the experimental soil during the dry early part of the growth season. A great deal of fertilizer nitrogen, phosphorus and potassium remained near the surface of the soil receiving surface dressing, and plants were not able to take up nutrients from the dry surface layer. On the contrary, the placed nutrients were deeper, in moister soil and better within the reach of wheat roots.

Any movement of ammonium nitrogen was not found by the used methods. Nitrate nitrogen appeared to move to a greater extent particularly in the irrigated plots.

Acknowledgement. The present experiment was carried out with the assistance of Keskusosuusliike Hankkija. 


\section{REFERENCES}

Chang S. \& Jackson M. L. 1957. Fractionation of soil phosphorus. Soil Sci. 84: 133-144.

Elonen P. \& NIEminen L. \& KArA O. 1967. Sprinkler irrigation on clay soils in Southern Finland: II. Effect on the grain yield of spring cereals. J. Sci. Agr. Soc. Finland 39: 00-00.

GoldEN L. E. 1961. Availability of native and radioactive fertilizer phosphorus to oats on Lake Charles clay. Soil Sci. 91: 349-355.

Hernonen R. 1960. A soil core sampler with provision for cutting successive layers. J. Sci. Agr. Soc. Finland 32: 176-178

KaIlA A. \& Hänninen P. 1961. Fertilizer nitrogen in soil. Ibid 33: 169-184.

Munson R. D. \& Nelson W. L. 1963: Movement of applied potassium in soils. J. agric. Food Chem. 11: $193-201$.

ScноғтеLD R. K. 1933. Rapid methods of examining soils II. The use of p-nitrophenol for assessing lime status. J. Agric. Sci. 23: 252-264.

TERĀSvUORI A. 1959. Uber das Bestimmen der Kationensorptionskapazität und des Basensättigungsgrades des Bodens. Valt. maatal. koetoim. julk. 175: 1-80. Helsinki.

TYLeR K. B. \& Broadbent F. E. \& Kondo V. 1958. Nitrogen movement in simulated cross sections in field soil. Agron. J. 50: 626-628.

\section{SELOSTUS:}

\section{SIJOITUSLANNOITUKSEN VAIKUTUS KEVÄTVEHNÄN KEHITYKSEEN}

\section{ERKKI AURA}

\section{Helsingin yliopiston maanviljelyskemian laitos}

Sijoituslannoitusta verrattiin pintalannoitukseen Espoon kauppalan alueella suoritetussa kenttäkokeessa. Koemaa oli hiesusavea ja koekasvina oli kevätvehnä. Lannoitteena oli normaali Y-lannos, ja sitä käytettiin 550 ja $1000 \mathrm{~kg}$ hehtaaria kohden.

Lannoitteen sijoittaminen $8 \mathrm{~cm}$ :n syvyyteen antoi keskimäärin $28 \%$ ja sijoittaminen $12 \mathrm{~cm}: \mathrm{n}$ syvyyteen $26 \%$ suuremman jyväsadon kuin pintalannoitus. Hajalevityksen saaneella maalla lannoitteen määrăn lisăäminen $550 \mathrm{~kg}$ :sta $1000 \mathrm{~kg}$ :aan hehtaaria kohden suurensi satoa vain $7 \%$, mutta maalla, johon lannoite oli sijoitettu $8 \mathrm{~cm}: n$ syvyyteen, sato suureni lannoitteen määrää lisättäessä $23 \%$.

Oraan kasvu ja ravinteiden saanti oli sijoituslannoituksen saaneella maalla paljon parempi kuin pintalannoituksen saaneella. Ravinteista typen otto oli suhteellisesti eniten suurentunut lannoitteen sijoittamisen ansiosta, jonkin verran vähemmän kaliumin otto ja vähiten fosforin otto.

Sijoitus nopeutti vehnän tuleentumista pintalannoitukseen verrattuna, mikä ilmeisesti johtui parantuneesta aikaisesta typen saannista ja parantuneesta fosforin saannista sijoittamisen ansiosta.

Maa-analyyseilla voitiin selittää, miksi sijoitus lisäsi voimakkaasti ravinteiden saantia. Pintalannoituksen saaneella maalla suuri osa lannoitteena annetuista ravinteista pysytteli kuivan alkukesän aikana lăhellă maan pintaa. Siten pintakerroksen kuivuessa kasvit eivät kyenneet käyttämään suurta osaa annetuista ravinteista. Sijoittamalla ravinteet saatiin syvemmälle, kosteampaan maahan ja paremmin juuriston ulottuville kuin pintaan levitettäessä.

Käytetyillä menetelmillä ei pystytty toteamaan ammoniumtypen liikkumista maassa. Sen sijaan nitraattityppi näytti liikkuvan suuremmassa määrin kuin ammoniumtyppi varsinkin sadetuksen saaneessa maassa. 